LINGUA, Vol. 14, No. 2, September 2017

p ISSN: 1979 9411; e ISSN: 2442 238X

Http://lingua.pusatbahasa.or.id; Email: presslingua@gmail.com

Center of Language and Culture Studies, Surakarta, Indonesia

Lanua, Maretin Ardile, Rhian; Saddhono, Kundharu \& Supana. 2017. Struktur Instrinsik

Novel Kepanggang Wirang Tiwiek SA and Implikasinya dalam Pembelajaran Bahasa Jawa di SMA.

Lingua, (2017), 14(2): 155 180.

\title{
STRUKTUR INSTRINSIK NOVEL KEPANGGANG WIRANG TIWIEK SA DAN IMPLIKASINYA DALAM PEMBELAJARAN BAHASA JAWA DI SMA
}

\author{
Rhian Ardila Maretin Lanua ${ }^{1}$ \\ Kundharu Saddhono ${ }^{2} \&$ Supana $^{3}$ \\ ${ }^{1}$ Thesis Supervisee \& ${ }^{2 \& 3}$ Thesis Supervisors \\ Graduate Program of Javanese Education, Sebelas Maret University \\ Jl. Ir. Sutami 36A Kentingan, Surakarta, Central Java, Indonesia \\ Email: adriellryo@gmail.com; kundharu@uns.ac.id \& supana77@ yahoo.com
}

\begin{abstract}
This study describes intrinsic structure of the Novel of Kepanggang Wirang (Burned Above the Shame) by Tiwiek SA and its implication to Javanese teaching at SMA. This study is qualittaive research and applied psychoanalysis as the research design. Data were collected using content analysis and interview. The study revealed that structural parts of the novel included: characters, plots, setting, theme, title, point of view, style and tone, symbolism, and irony. In addition, Kepanggang Wirang is relevant to teaching Javanese in SMA as its language and education values are in support to Basic Competence in SMA Curriculum.
\end{abstract}

Keywords: characters, conflict, plot, intrinsic values.

Analisis sebuah novel tak lepas dengan analisis struktural, yaitu analisis unsur instrinsik yang meliputi tema, alur, penokohan, setting dan amanat. Unsur instrinsik tersebut akan melengkapi satu sama lain sehingga menghasilkan sebuah karya yang indah. Oleh sebab itu, unsur instrinsik sangat penting dalam menentukan isi sebuah novel.

Novel dihasilkan oleh pengarang dengan memuat cerita tentang kehidupan di lingkungan sekitar pengarang. Dalam kehidupan pengarang tentu saja tidak terlepas dari problem-problem sosial. Banyak faktor yang menjadi penyebab hal ini, dianataranya adalah persoalan ekonomi, budaya, biologis dan psikologis yang dialami oleh masing-masing kelompok maupun individu di lingkungannya.

Novel Kepanggang Wirang (selanjutnya Kepanggang Wirang) dikaji berdasarkan teori struktural dalam karya sastra. Kepanggang Wirang adalah sebuah novel berbahasa Jawa karya Tiwiek SA yang terbit pada tahun 2016. Novel ini menceritakan tentang Wirastri, istri dari Joni Kismanto yang menjadi korban perceraian karena sang suami menikah lagi dengan mantan pacar semasa SMA. Joni Kismanto bingung bagaimana caranya menceraikan Wirastri karena Wirastri tidak memiliki kesalahan yang menyebabkan Joni Kismanto menceraikannya. Akhirnya Joni Kismanto melakukan rencana bersama temannya untuk tidur dengan Wirastri. Wirastri yang diberi obat perangsang dalam minumannya akhirnya tertidur di kamar, dan ketika bangun dia sudah tidak mengenakan busana dan terdapat seorang laki-laki tidur bersamanya. 
LINGUA, Vol. 14, No. 2, September 2017

p ISSN: 1979 9411; e ISSN: 2442 238X

Http://lingua.pusatbahasa.or.id; Email: presslingua@gmail.com

Center of Language and Culture Studies, Surakarta, Indonesia

Lanua, Maretin Ardile, Rhian; Saddhono, Kundharu \& Supana. 2017. Struktur Instrinsik

Novel Kepanggang Wirang Tiwiek SA and Implikasinya dalam Pembelajaran Bahasa Jawa di SMA.

Lingua, (2017), 14(2): 155 180.

Strategi Joni Kismanto berhasil, Wirastri telah menjadi seorang janda, dan Joni Kismanto telah menikah lagi dengan mantan pacarnya semasa SMA yang bernama Suminingrum.

Setelah menjadi janda, Wirastri berwirausaha di Bali berkat bantuan dari seseorang yang dia temui di Terminal. Wirastri juga belajar bela diri. Ilmu bela diri yang dipelajari sudah cukup dikuasai, Wirastri ingin berbalas dendam dengan lelaki yang telah merusak harga diri dan kehidupannya. Berbagai strategi matang sudah disiapkan Wirastri. Setelah menentukan waktu yang tepat, Wirastri kembali ke Kediri mencari lelaki yang telah merusak harga dirinya.

Kepanggang Wirang merupakan novel yang menarik untuk membahas tokoh utama yang ada di dalamnya. Wirastri yang merasa harga dirinya sudah dirusak oleh laki-laki lain membuat Wirastri naik tikam dan membalas perbuatan keji tersebut. Gejolak kejiwaan Wirastri semakin membara ketika mengetahui bahwa perbuatan yang merusak harga dirinya itu ternyata sudah direncanakan oleh suaminya sendiri supaya dia bisa menikah dengan mantan kekasihnya semasa SMA yang juga janda karena ditinggal mati suaminya.

Sesuai uraian di atas, tujuan penelitian ini adalah untuk: (1) Mendeskripsikan dan menjelaskan struktur instrinsik novel Kepanggang Wirang karya Tiwiek SA, dan (2) Mendeskripsikan dan menjelaskan relevansi terhadap pembelajaran Bahasa Jawa di SMA.

Penelitian ini menggunakan pendekatan struktural untuk menganalisis isi novel. Pendekatan struktural merupakan pendekatan yang menekankan pada hubungan antar unsurnya. Suatu karya sastra, fiksi atau puisi menurut kaum strukturalisme adalah suatu totalitas yang dibangun secara koherensif oleh berbagai unsur pembangunnya. Menurut Sangidu (2004:16) struktur karya sastra harus dilihat sebagai totalitas karena sebuah struktur terbentuk dari serangkaian unsur-unsurnya.

Sumarjo (1991:24) mengemukakan novel adalah bentuk sastra yang paling populer di dunia. Bentuk sastra ini banyak dicetak dan paling banyak beredar, lantaran daya komunitasnya yang luas pada masyarakat. Novel adalah bentuk karya sasta yang di dalamnya terdapat nilai-nilai budaya sosial, moral dan pendidikan. Novel merupakan karya sastra yang mempunyai dua unsur, yaitu unsur instrinsik dan unsur ekstrinsik yang keduanya saling berhubungan dan sangat berpengaruh dalam kehadiran sebuah karya sastra.

Analisis struktural karya sastra dapat dilakukan dengan mengidentifikasi, mengkaji, serta mendeskripsikan fungsi dan hubungan atas unsur intrinsik yang bersangkutan. Analisis struktural pada dasarnya bertujuan memaparkan secermat mungkin fungsi dan keterkaitan antar berbagai unsur karya sastra yang secara bersama menghasilkan keseluruhan. Analisis struktural tidak cukup dilakukan hanya sekedar mendata unsur tertentu sebuah karya fiksi. Namun yang terpenting adalah menunjukkan bagaimana hubungan antar unsur itu, dan sumbangan apa yang diberikan terhadap tujuan estetik dan makna keseluruhan yang ingin dicapai (Nurgiyantoro, 2010:37).

Pendekatan struktural merupakan langkah awal dalam melakukan penelitian karya sastra sebelum melakukan pendekatan selanjutnya. Pendekatan struktural sebagai 
LINGUA, Vol. 14, No. 2, September 2017

p ISSN: 1979 9411; e ISSN: 2442 238X

Http://lingua.pusatbahasa.or.id; Email: presslingua@gmail.com

Center of Language and Culture Studies, Surakarta, Indonesia

Lanua, Maretin Ardile, Rhian; Saddhono, Kundharu \& Supana. 2017. Struktur Instrinsik

Novel Kepanggang Wirang Tiwiek SA and Implikasinya dalam Pembelajaran Bahasa Jawa di SMA.

Lingua, (2017), 14(2): 155 180.

cara untuk memahami karya sastra berdasarkan unsur-unsur intrinsik membentuk karya sastra yang menghasilkan makna menyeluruh antara lain meliputi alur, penokohan, tema, setting, dan amanat. Menurut Atar Semi mengatakan bahwa bila hendak mengkaji sebuah karya sastra, maka yang harus dikaji atau diteliti adalah aspek yang membangun karya tersebut seperti tema, alur, latar, penokohan, gaya penulisan, gaya bahasa serta hubungan harmonis antar aspek yang mampu membuatnya menjadi sebuah karya sastra (Semi, 1993:67). Analisis struktural bertujuan hanya untuk membongkar dan memaparkan secermat, seteliti, sedetail, dan sedalam mungkin keterjalinan semua unsur dan aspek karya sastra yang bersama-sama menghasilkan makna menyeluruh (Teeuw dalam Sangidu, 2004:15). Dalam penelitian ini, penulis menggunakan teori struktural Robert Stanton yang meliputi: fakta-fakta cerita (karakter, alur, latar), tema, saranasarana sastra (judul, sudut pandang, gaya dan tone, simbolisme dan ironi).

\section{Fakta-Fakta Cerita}

Sebuah cerita memiliki struktur faktual yang membangun cerita tersebut. Struktur faktual merupakan salah satu aspek cerita dan bukanlah menjadi bagian terpisah dari sebuah cerita (Stanton, 2007:22). Fakta-fakta cerita atau struktur faktual tersebut terdiri dari tiga komponen yaitu karakter, alur, dan latar.

\section{a. Karakter}

Stanton (2007:33) mengemukakan karakter biasanya dipakai dalam dua konteks. Pertama, karakter merujuk pada individu-individu yang muncul dalam cerita. Kedua, karakter merujuk pada percampuran dari berbagai kepentingan, keinginan, emosi, dan prinsip moral dari individu-individu. Dalam sebagian besar cerita dapat ditemukan satu "karakter utama" yaitu karakter yang terkait dengan semua peristiwa yang berlangsung dalam cerita. Karakter atau perwatakan tokoh bisa dilukiskan melalui: 1) Deskripsi eksplisit, 2) Penggambaran pengarang, 3) Pernyataan tokoh lain.

\section{b. Alur}

Alur merupakan rangkaian peristiwa dalam sebuah cerita. Istilah alur biasanya terbatas pada peristiwa-peristiwa yang terhubung secara kausal saja. Peristiwa kausal merupakan peristiwa yang menyebabkan atau menjadi dampak dari berbagai peristiwa lain dan tidak dapat diabaikan karena akan berpengaruh pada keseluruhan karya. Peristiwa kausal tidak terbatas pada hal-hal yang fisik saja seperti ujaran atau tindakan, tetapi juga mencakup perubahan sikap karakter, kilasan-kilasan pandangannya, keputusan-keputusannya dan segala yang menjadi variabel pengubah dirinya.

Alur merupakan tulang punggung cerita. Alur dapat membuktikan dirinya sendiri meskipun jarang diulas panjang lebar dalam sebuah analisis. Sebuah cerita tidak akan pernah seutuhnya dimengerti tanpa adanya pemahaman terhadap peristiwaperistiwa yang mempertautkan alur, hubungan kausalitas, dan keberpengaruhannya. Alur memiliki bagian awal, tengah, dan akhir serta dapat menciptakan bermacammacam kejutan, dan memunculkan sekaligus mengakhiri ketegangan-ketegangan (Stanton, 2007:26). 
LINGUA, Vol. 14, No. 2, September 2017

p ISSN: 1979 9411; e ISSN: 2442 238X

Http://lingua.pusatbahasa.or.id; Email: presslingua@gmail.com

Center of Language and Culture Studies, Surakarta, Indonesia

Lanua, Maretin Ardile, Rhian; Saddhono, Kundharu \& Supana. 2017. Struktur Instrinsik

Novel Kepanggang Wirang Tiwiek SA and Implikasinya dalam Pembelajaran Bahasa Jawa di SMA.

Lingua, (2017), 14(2): 155 180.

\section{c. Latar}

Latar atau setting merupakan tempat dan waktu terjadinya cerita. Suatu cerita pada hakikatnya merupakan suatu pelukisan peristiwa atau kejadian yang dilakukan oleh beberapa tokoh pada suatu waktu di suatu tempat. Latar adalah lingkungan yang melingkupi sebuah peristiwa dalam cerita, dan juga suasana dalam cerita semesta yang berinteraksi dengan peristiwa-peristiwa yang sedang berlangsung. Latar dapat berwujud dekor, waktu, cuaca, atau suatu periode sejarah. Meskipun tidak langsung merangkum sang karakter utama, latar dapat merangkum orang-orang yang menjadi dekor dalam cerita (Stanton, 2007:35).

\section{Tema}

Stanton (2007:36-37) mengemukakan tema merupakan aspek cerita yang sejajar dengan 'makna' dalam pengalaman manusia, sesuatu yang menjadikan suatu pengalaman begitu diingat. Ada banyak cerita yang menggambarkan dan menelaah kejadian atau emosi yang dialami manusia seperti cinta, derita, rasa takut, kedewasaan, keyakinan, dan pengkhianatan manusia terhadap diri sendiri. Tarigan (2000:125) mengemukakan tema merupakan pandangan hidup tertentu atau perasaan tertentu mengenai kehidupan atau rangkaian nilai-nilai tertentu yang membentuk atau membangun dasar/gagasan utama dari sebuah karya sastra. Tema merupakan gagasan pokok yang mendasari cerita dan memiliki kedudukan yang dominan sehingga dapat mempersatukan unsur secara bersama-sama membangun sebah karya sastra. Selain itu tema bisa diilhami dari konflik yang terjadi dalam kehidupan masyarakat.

\section{Sarana-Sarana Sastra}

Sarana-sarana sastra dapat diartikan sebagai metode pengarang memilih dan menyusun detail cerita agar tercapai pola-pola yang bermakna. Metode ini perlu karena dengannya pembaca dapat melihat berbagai fakta melalui kacamata pengarang, memahami apa maksud fakta-fakta tersebut sehingga pengalaman pun dapat dibagi (Stanton, 2007:46-47). Sarana-sarana sastra meliputi lima hal.

\section{a. Judul}

Judul hendaknya harus selalu relevan terhadap karya yang diampunya sehingga keduanya dapat membentuk satu kesatuan. Judul biasanya mengacu pada sang karakter utama atau satu latar tertentu. Sebuah judul juga kerap memiliki beberapa tingkatan makna (Stanton, 2007:51).

\section{b. Sudut Pandang}

Secara singkat Stanton mengatakan bahwa sudut pandang merupakan pusat kesadaran tempat kita dapat memahami setiap peristiwa di dalam sebuah cerita. Tempat dan sifat 'sudut pandang' tidak muncul serta-merta. Pengarang harus memilih sudut pandangnya dengan hati-hati agar cerita yang diutarakannya menimbulkan efek yang pas (2007:52-53). Dari sisi tujuan, sudut pandang terbagi menjadi empat: 
LINGUA, Vol. 14, No. 2, September 2017

p ISSN: 1979 9411; e ISSN: 2442 238X

Http://lingua.pusatbahasa.or.id; Email: presslingua@gmail.com

Center of Language and Culture Studies, Surakarta, Indonesia

Lanua, Maretin Ardile, Rhian; Saddhono, Kundharu \& Supana. 2017. Struktur Instrinsik

Novel Kepanggang Wirang Tiwiek SA and Implikasinya dalam Pembelajaran Bahasa Jawa di SMA.

Lingua, (2017), 14(2): 155 180.

1) Pada 'orang pertama-utama', sang karakter utama bercerita dengan kata katanya sendiri.

2) Pada 'orang pertama-sampingan', cerita dituturkan oleh satu karakter bukan utama (sampingan).

3) Pada 'orang ketiga-terbatas', pengarang mengacu pada semua karakter dan memosisikannya sebagai orang ketiga tetapi hanya menggambarkan apa yang dapat dilihat, didengar, dan dipikirkan oleh satu orang karakter saja.

4) Pada 'orang ketiga-tidak terbatas', pengarang mengacu pada setiap karakter dan memosisikannya sebagai orang ketiga.

\section{c. Gaya dan Tone}

Dalam sastra, gaya adalah cara pengarang dalam menggunakan bahasa. Meski dua orang pengarang memakai alur, karakter, dan latar yang sama, hasil tulisan keduanya bisa sangat berbeda. Perbedaan tersebut secara umum terletak pada bahasa dan menyebar dalam berbagai aspek seperti kerumitan, ritme, panjang-pendek kalimat, detail, humor, kekonkritan, dan banyaknya imaji dan metafora. Campuran dari berbagai aspek di atas (dengan kadar tertentu) akan menghasilkan gaya (Stanton, 2007:61).

Tone adalah sikap emosional pengarang yang ditampilkan dalam cerita. Tone bisa menampak dalam berbagai wujud, baik yang ringan, romantis, ironis, misterius, senyap, bagai mimpi, atau penuh perasaan. Pada porsi tertentu tone dimunculkan oleh fakta-fakta, akan tetapi yang terpenting adalah pilihan detail pengarang ketika menyodorkan fakta-fakta itu dan tentu saja, gaya pengarang sendiri (Stanton, 2007:63).

\section{d. Simbolisme}

Gagasan dan emosi terkadang tampak nyata bagaikan fakta fisis padahal sejatinya, kedua hal tersebut tidak dapat dilihat dan sulit dilukiskan. Salah satu cara untuk menampilkan kedua hal tersebut agar tampak nyata adalah melalui 'simbol'; simbol berwujud detail-detail konkrit dan faktual dan memiliki kemampuan untuk memunculkan gagasan dan emosi dalam pikiran pembaca. Simbol dapat berwujud apa saja, dari sebutir telur hingga latar cerita seperti satu objek, beberapa objek bertipe sama, substansi fisis, bentuk, gerakan, warna, suara, atau keharuman. Semua hal tersebut dapat menghadirkan satu fakta terkait kepribadian seorang manusia, ketidakacuhan alam terhadap penderitaan manusia, ambisi yang semu, kewajiban manusia, atau romantisme masa muda (Stanton, 2007:64).

Dalam fiksi, simbolisme dapat memunculkan tiga efek. Pertama, sebuah simbol yang muncul pada satu kejadian penting dalam cerita menunjukan makna peristiwa tersebut. Kedua, satu simbol yang ditampilkan berulang-ulang mengingatkan kita akan beberapa elemen konstan dalam semesta cerita. Ketiga, sebuah simbol yang muncul pada konteks yang berbeda-beda akan membantu kita menemukan tema (Stanton, 2007:65). 
LINGUA, Vol. 14, No. 2, September 2017

p ISSN: 1979 9411; e ISSN: 2442 238X

Http://lingua.pusatbahasa.or.id; Email: presslingua@gmail.com

Center of Language and Culture Studies, Surakarta, Indonesia

Lanua, Maretin Ardile, Rhian; Saddhono, Kundharu \& Supana. 2017. Struktur Instrinsik

Novel Kepanggang Wirang Tiwiek SA and Implikasinya dalam Pembelajaran Bahasa Jawa di SMA.

Lingua, (2017), 14(2): 155 180.

\section{e. Ironi}

Stanton (2007:71) mengatakan bahwa secara umum, ironi dimaksudkan sebagai cara untuk menunjukan bahwa sesuatu berlawanan dengan apa yang telah diduga sebelumnya. Ironi dapat ditemukan dalam hampir semua cerita. Bila di manfaatkan dengan benar, ironi dapat memperkaya cerita seperti menjadikannya menarik, menghadirkan efek-efek tertentu, humor atau pathos memperdalam karakter, merekatkan struktur alur, menggambarkan sikap pengarang, dan menguatkan tema.

Dalam dunia fiksi ada dua jenis ironi yang dikenal luas yaitu 'ironi dramatis' dan 'tone ironis'. Ironi dramatis atau ironi alur dan situasi biasanya muncul melalui kontras diametris antara penampilan dan realiatas, atau antara harapan dengan apa yang sebenarnya terjadi. Pasangan elemen-elemen di atas terhubung satu sama lain secara logis. Sedangakan tone ironis atau ironi verbal digunakan untuk menyebut cara berekspresi yang mengungkapkan makna dengan cara berkebalikan (Stanton, 2007:72).

\section{METODE}

Penelitian ini ialah penelitian deskriptif kualitatif. Jenis penelitian ini ialah penelitian sastra yang mengkaji novel Kepanggang Wirang karya Tiwiek SA. Sumber data primer penelitian ini adalah novel Kepanggang Wirang karya Tiwiek SA. Sumber data sekundernya adalah pengarang novel Kepanggang Wirang, guru Bahasa Jawa SMA dan siswa SMA. Data penelitian ini berupa kata-kata, kalimat, frasa, alinea, dan wacana. Data diperoleh melalui kajian dokumen dan wawancara tak terstruktur. Wawancara dengan pengarang digunakan untuk mengetahui riwayat hidup pengarang, hasil-hasil karyanya serta keterangan-keterangan yang mendukung penelitian. Wawancara tak berstruktur digunakan untuk menemukan informasi yang bukan baku (Moleong, 2000:190). Wawancara juga dilakukan dengan guru dan siswa. Wawancara dilakukan dengan tanya jawab mengalir seperti dalam percakapan sehari-hari. Data dianalisis menggunakan teknik analisis isi, dimulai dengan peneliti menemukan unsurunsur struktural novel dan menganlisis fakta-fakta cerita, sarana-sarana sastra, dan keterkaitannya dengan unsur sastra lainnya.

\section{HASIL}

\section{Struktur Instrinsik Novel Kepanggang Wirang Karya Tiwiek SA}

Karya sastra novel selalu menceritakan tokoh dengan menggunakan unsur instrinsik maupun ekstrinsik untuk membantu pembaca dalam memahami cerita sebuah novel. Analisis Kepanggang Wirang dimulai dari unsur instrinsik: fakta-fakta cerita (karakter, alur, latar), tema, sarana-sarana sastra (judul, sudut pandang, gaya dan tone, simbolisme dan ironi).

\section{Fakta-Fakta Cerita}

Fakta-fakta cerita meliputi karakter, alur dan latar. Elemen-elemen tersebut apabila disatukan dinamakan dengan struktur faktual atau tingkatan faktual cerita. Ketiga unsur itu menjelaskan berbagai bentuk peristiwa/kejadian yang menjadi bagian penting dari masing-masing cerita. 
LINGUA, Vol. 14, No. 2, September 2017

p ISSN: 1979 9411; e ISSN: 2442 238X

Http://lingua.pusatbahasa.or.id; Email: presslingua@gmail.com

Center of Language and Culture Studies, Surakarta, Indonesia

Lanua, Maretin Ardile, Rhian; Saddhono, Kundharu \& Supana. 2017. Struktur Instrinsik

Novel Kepanggang Wirang Tiwiek SA and Implikasinya dalam Pembelajaran Bahasa Jawa di SMA.

Lingua, (2017), 14(2): 155 180.

\section{Karakter}

Karakter merupakan unsur penting dan menjadi salah satu unsur pembangun dalam sebuah karya sastra. Menurut Stanton, karakter biasanya dipakai dalam dua konteks. Konteks pertama, karakter merujuk pada individu-individu yang muncul dalam cerita. Karakter yang kedua, karakter yang merujuk pada percampuran dari berbagai kepentingan, keinginan, emosi, dan prinsip moral dari individu-individu. Karakter terdiri dari karakter utama atau karakter mayor dan karakter bawahan atau karakter minor. Karakter seseorang juga bisa diketahui dari nama, deskripsi eksplisit, dan komentar pengarang tentang karakter yang bersangkutan.

\section{a. Karakter Utama atau Mayor}

\section{1) Joni Kismanto}

Joni Kismanto merupakan seorang kepala cabang pada bank swasta di Kediri. Berikut kutipan yang menyakatan kedudukan Joni.

"Joni Kismanto, pimpinan Bank Dana Arta kuwi kahanane melas banget."(Tiwiek SA, 2016: 4)

\section{Terjemahan:}

"Joni Kismanto, Pimpinan Bank Dana Arta itu keadaannya sangat menyedihkan." (Tiwiek SA, 2016: 4)

Joni Kismanto merupakan sosok yang memiliki ambisi dan cita-cita yang kuat. Dia ingin membuktikan kepada orang lain walaupun dia bukan dari keturunan keluarga ningrat namun dia harus bisa sederajat dengan orang kaya. Namun, Joni Kismanto juga seorang yang licik, dia merekayasa perselingkuhan istrinya agar dia bisa menceraikan istrinya dan menikah dengan pacar semasa SMA. Berikut kutipannya.

"Mas Joni kepengin krama karo pacare biyen sing saiki wis dadi warandha, Mbak. Asmane Suminingrum, asli Sala. Sarnehe wes kadhung kagungan garwa panjenengan,mula banjur gawe rekayasa. Mas Joni pengin megat panjenengan tanpa kawistara."(Tiwiek SA, 2016: 103)

\section{Terjemahan:}

"Mas Joni ingin menikah dengan mantan pacarnya yang sekarang sudah menjadi janda, Mbak. Namanya Suminingrum, asli Solo. Karena sudah terlanjur punya istri kamu, lalu membuat rekayasa. Mas Joni ingin menceraikan kamu dengan cara halus." (Tiwiek SA,2016: 103)

\section{2) Wirastri}

Wirastri merupakan salah satu tokoh utama dalam Kepanggang Wirang. Wirastri merupakan istri dari Joni Kismanto yang dikenalkan dan dijodohkan dengan keponakanpemilik rumah kontrakan Joni Kismanto semasa awal kerja. Wirastri sosok istri yang berbakti kepada suami. Istri yang pandai memasak dan juga setia terhadap 
LINGUA, Vol. 14, No. 2, September 2017

p ISSN: 1979 9411; e ISSN: 2442 238X

Http://lingua.pusatbahasa.or.id; Email: presslingua@gmail.com

Center of Language and Culture Studies, Surakarta, Indonesia

Lanua, Maretin Ardile, Rhian; Saddhono, Kundharu \& Supana. 2017. Struktur Instrinsik

Novel Kepanggang Wirang Tiwiek SA and Implikasinya dalam Pembelajaran Bahasa Jawa di SMA. Lingua, (2017), 14(2): 155 180.

keluarga. Selain itu Wirastri juga berpenampilan menarik walapun hanya berpendidikan rendah. Berikut kutipannya:

"Mengkono nganti lumaku tetaunan. Nganti Joni njur rabi entuk kenya keponakane sing dipondhoki. Kenya prasaja lan ora pati ayu, asal Tulungagung. Arane Wirastri." (Tiwiek SA, 2016: 20)

\section{Terjemahan:}

"Begitu hingga berjalan bertahun-tahun. Hingga Joni kemudian menikandengan gadis keponakan pemilik kontrakannya. Gadis baik dan tidak terlalu cantik, dari Tulungagung. Namanya Wirastri.” (Tiwiek SA, 2016: 20)

\section{3) Sumingingrum}

Sumingingrum merupakan pacar Joni Kismanto semasa duduk di bangku sekolah. Suminingrum lebih muda dari Joni Kismanto, memiliki paras wajah yang cantik. Suminingrum merupakan keturunan dari keluarga yang terpandang. Suminingrum merupakan anak yang berbakti terhadap kedua orangtuanya, terbukti dari surat yang dia tulis untuk Joni Kismanto perihal perjodohannya dengan laki-laki pilihan orang tuanya. Berikut kutipannya:

"... aku mung bocah wadon Mas. Kathik wiwit cilik wis digladhi mbangun miturut marang wong tuwa. Rasane ora mentala lan ngrasa dosa arep mbangkang kersane wong tuwa. Mula apuranen aku dene kepeksa mblenjani janji ora sida urip bebarengan karo sliramu..." (Tiwiek SA, 2016: 17)

\section{Terjemahan:}

“... saya hanya anak perempuan Mas. Sejak kecil sudah dididik berbakti kepada orang tua. Terasa berdosa apabila menolak keinginan orang tua. Maka maafkan saya terpaksa harus mengingkari janji untuk hidup bersamamu..." (Tiwiek SA, 2016: 17)

\section{b. Karakter Bawahan atau Minor}

\section{1) Mbok Tarminah}

Mbok Tarminah merupakan pembantu di rumah Joni Kismanto. Kesetiaannya mengabdi menjadi pembantu rumah tangga menjadikan kedua anak Joni Kismanto nyaman dengan Mbok Tarminah. Terbukti ketika Joni Kismanto menikah lagi dengan Suminingrum yang membuat kedua anaknya iri karena merasa kasih sayangnya kepada kedua anaknya berkurang ketika Suminingrum hadir di tengah-tengah keluarga mereka. Berikut kutipannya:

"Kasenengan iku ora kanggo dheweke. Kasenengan iku mung mligi kanggo bapake lan ibune anyar. Bocah loro malah prasasat kesingkir. Saiki lagi krasa wigatine ibu asli ing sisihe. Siji-sijine pawongan sing bisa aweh panglipur mung Mbok Tarminah. Abdi tuwa iku ora towong menehi pitutur lan panglipur." (Tiwiek SA, 2016: 58) 
LINGUA, Vol. 14, No. 2, September 2017

p ISSN: 1979 9411; e ISSN: 2442 238X

Http://lingua.pusatbahasa.or.id; Email: presslingua@gmail.com

Center of Language and Culture Studies, Surakarta, Indonesia

Lanua, Maretin Ardile, Rhian; Saddhono, Kundharu \& Supana. 2017. Struktur Instrinsik

Novel Kepanggang Wirang Tiwiek SA and Implikasinya dalam Pembelajaran Bahasa Jawa di SMA.

Lingua, (2017), 14(2): 155 180.

\section{Terjemahan:}

"Kebahagiaan itu tidak untuk dirinya. Kebahagiaan itu hanya untuk ayahnya dan ibu barunya. Kedua anak itu seketika tersingkir. Sekarang baru terasa perhatian dari ibu kandung di sampingnya. Satu-satunya orang yang bisa menghibur hanya Mbok Tarminah. Pembantu tua itu tidak berhenti menasihati dan menghibur." (Tiwiek SA, 2016: 58)

\section{2) Pujilestari}

Pujilestari merupakan anak sulung Joni Kismanto dan Wirastri. Gadis remaja yang duduk di bangku SMA itu memiliki sifat keingintahuannya yang tinggi. Berikut kutipannya:

"Pujilestari -anak mbarepe Joni Kismanto- ngrasa ora kepenak meruhi bapake. Njur miterang marang ibune, "Buk, ngapa ta Bapak kok ketara rengu?" (Tiwiek SA, 2016: 30)

\section{Terjemahan:}

"Pujilestari -anak sulung Joni Kismanto- merasa tidak nyaman ketika melihat Bapaknya. Kemudian bertanya kepada ibunya, "Buk, kenapa Bapak terlihat muram?" (Tiwiek SA, 2016: 30)

\section{3) Dwi Saksono}

Dwi Saksono merupakan anak bungsu dari Joni Kismanto dan Wirastri. Dwi Saksono yang hobi makan ini memiliki sifat yang acuh dengan keadaan keluarganya, terbukti ketika kakak dan ibuknya merasa bingung dengan perubahan sikap bapaknya, Dwi Saksono tidak memperdulikannya. Berikut kutipannya:

"Ala Mbak, kok peduli amat. Mbok ya wis ben Bapak ora kersa dhahar neng ndalem. Karuwan jatahe kanggo aku wae." (Tiwiek SA, 2016: 32)

\section{Terjemahan:}

"Ala Mbak, Peduli amat. Biarkan saja Bapak tidak mau makan di rumah. Kebetulan bagiannya buat saya saja." (Tiwiek SA, 2016: 32)

\section{4) Pradopo}

Pradopo merupakan anak buah dari Joni Kismanto. Pekerjaannya yang serabutan menjadikannya selalu menerima tawaran untuk melakukan apa saja yang penting mendapat upah. Berikut kutipannya:

"Pradopo dhewe ora duwe gaweyan maton. Biyen pancen tau dadi karyawane Gudhang Garam. Ning banjur dilerene awit kadenangan ndhemeni bojone kancane. Saploke leren saka Gudhang Garam, ora duwe gaweyan maton maneh. Sing kerep ditindakake makelaran." (Tiwiek SA, 2016: 94)

\section{Terjemahan:}


LINGUA, Vol. 14, No. 2, September 2017

p ISSN: 1979 9411; e ISSN: 2442 238X

Http://lingua.pusatbahasa.or.id; Email: presslingua@gmail.com

Center of Language and Culture Studies, Surakarta, Indonesia

Lanua, Maretin Ardile, Rhian; Saddhono, Kundharu \& Supana. 2017. Struktur Instrinsik

Novel Kepanggang Wirang Tiwiek SA and Implikasinya dalam Pembelajaran Bahasa Jawa di SMA.

Lingua, (2017), 14(2): 155 180.

"Pradopo sendiri tidak memiliki pekerjaan tetap. Dulu memang pernah menjadi karyawan Gudang Garam. Tapi dipecat karena selingkuh dengan istri temannya. Semenjak dipecat dari Gudang Garam, tidak memiliki pekerjaan tetap lagi. Yang sering dilakukan adalah makelaran.” (Tiwiek SA, 2016: 94)

\section{5) Pak Wiryono}

Pak Wiryono merupakan orang tua kandung Wirastri yang tinggal di Tulungagung. Sosok laki-laki tua ini bekerja sebagai petani di desa. Pak Wiryono memiliki hobi merokok. Berikut kutipannya:

"Wiyah, mati urip ki urusane sing ngecet Lombok! Ora nyandu rokok yen pancen wis dikersakake, ya bakal mati. Contone Pak Guru Barno kae. Sajege urip ora nate ngrokok, e...lagi umur piro ujug-ujug seda. Bareng aku iki wis kliwat pitung puluh, gene kok isih rosa." (Tiwiek SA, 2016: 62)

\section{Terjemahan:}

"Hidup mati itu sudah takdir yang mewarnai cabai (Tuhan)! bukan pecandu rokok kalaupun sudah ditakdirkan, ya bakal mati. Contohnya Pak Guru Barno, semasa hidup tidak pernah merokok,e... baru usia berapa tiba-tiba meninggal. Aku yang sudah lewat tujuh puluh, sampai sekarang masih kuat." (Tiwiek SA, 2016: 62)

\section{6) Mbok Wiryono}

Mbok Wiryono merupakan ibu kandung Wirastri. Wanita tua itu mencerminkan sosok wanita desa yang masih polos dan sederhana. Bekerja sebagai petani untuk mencukupi kehidupan sehari-hari seperti Pak Wiryono. Mbok Wiryono juga digambarkan sebagai sosok yang sayang terhadap keluarganya.

\section{7) Pak Made Tantra}

Pak Made Tantra merupakan seseorang yang menolong Wirastri ketika kecopetan di terminal Malang. Dalam novel ini, Pak Made Tantra digambarkan sebagai sosok orang tua yang ahli dibidang bela diri. Terbukti ketika menolong Wirastri dalam melawan pencuri, Pak Made Tantra berhasil mengalahkan pencuri tersebut. Berikut ini kutipannya:

"Weruh patrape Wirastri, si priya sajak kegugah. Lan bareng ngerti underane, ujug-ujug priya kasebut mletik oncat, mbujung si klambi lorek. Tandange cukat trengginas, solahe angel ditut pandulu. Bab kasebut gawe gawoke wong-wong kang nyekseni. Luwih gawok maneh bareng sasat sakedhep netra, si priya klambi lorek wis ketututan." (Tiwiek SA, 2016: 86)

\section{Terjemahan:}

"Melihat apa yang dialami Wirastri, lelaki itu seakan tergugah hatinya. Dan setelah tau penyebabnya, tiba-tiba lelaki itu segera bertindak, mengejar si baju bergaris. Pergerakannya sigap dan cepat, seolah sulit dengan logika. Hal tersebut 
LINGUA, Vol. 14, No. 2, September 2017

p ISSN: 1979 9411; e ISSN: 2442 238X

Http://lingua.pusatbahasa.or.id; Email: presslingua@gmail.com

Center of Language and Culture Studies, Surakarta, Indonesia

Lanua, Maretin Ardile, Rhian; Saddhono, Kundharu \& Supana. 2017. Struktur Instrinsik

Novel Kepanggang Wirang Tiwiek SA and Implikasinya dalam Pembelajaran Bahasa Jawa di SMA.

Lingua, (2017), 14(2): 155 180.

membuat kagum orang yang melihatnya. Lebih heran lagi sekejap mata, lelaki

berbaju garis sudah berhasil dikejar." (Tiwiek SA, 2016: 86)

\section{8) Dalijo}

Tokoh Dalijo dalam Kepanggang Wirang digambarkan sebagai seorang kepala satpam di bank Dana Arta yang dipimpin oleh Joni Kismanto. Dalijo seorang pegawai negeri dengan pangkat yang belum tinggi sehingga terpaksa pensiun dini. Berikut kutipannya:

"Dalijo dudu golongane wong jahat. Apa maneh biyene dheweke klebu 'wonge negara'. Merga ijasahe mung SR, ing pangkat iseh endhek lan umur durung patiya tuwa, kepeksa wis purna tugas alias pensiun.”(Tiwiek SA, 2016: 140)

\section{Terjemahan:}

"Dalijo bukan golongan orang jahat. Apa lagi dulunya tergolong 'aparat negara'. Karena ijazahnya hanya SR,dan pangkatnya belum terlalu tinggi dan umur yang belum terlalu tua, terpaksa harus purna tugas atau pensiun." (Tiwiek SA, 2016: 140)

\section{9) Dhugel}

Dhugel merupakan seorang preman dan juga seorang mantan narapidana. Dhugel dalam Kepanggang Wirang digambarkan seorang yang memiliki postur badan besar, pendek dan kulit berwarna hitam dengan bentuk kepala yang botak. Dhugel juga digambarkan sebagai seorang pengangguran, terbukti disaat jam kerja, Dhugel hanya bersantai-santai di rumah. Berikut kutipannya:

"Esuk iku pawongan gedhe endhek kulit ireng sirah plonthos iku lagi njegogroh ing emperan ngarep. Kemul sarung karo ngrokok pah-poh. Ing sandhinge katon piring kosong tilas wadhah sarapan. Njur gelas gedhe isi wedang kopi kari separo. Dhugel katon nglaras banget." (Tiwiek SA, 2016: 141)

\section{Terjemahan:}

"Pagi itu seorang berbadan besar pendek kulit hitam kepala botak itu sedang duduk santai di serambi depan. Berselimut sarung sambil merokok.di sampingnya terlihat piring kosong bekas tempat sarapan. Dan juga gelas besar berisikan kopi yang tinggal setengah. Dhugel terlihat santai." (Tiwiek SA, 2016: 141)

\section{0) Gemplo}

Gemplo merupakan tokoh pembantu dalam Kepanggang Wirang. Dalam novel tersebut, tokoh Gemplo berperan sebagai seorang penjahat teman dari Dhugel yang sama-sama seorang penjahat. Gemplo dalam novel tersebut digambarkan sebagai seorang penjahat yang kurang cerdas, tidak seperti Dhugel yang selalu berfikir dahulu sebelum bertindak. Berikut ini kutipannya: 
LINGUA, Vol. 14, No. 2, September 2017

p ISSN: 1979 9411; e ISSN: 2442 238X

Http://lingua.pusatbahasa.or.id; Email: presslingua@gmail.com

Center of Language and Culture Studies, Surakarta, Indonesia

Lanua, Maretin Ardile, Rhian; Saddhono, Kundharu \& Supana. 2017. Struktur Instrinsik

Novel Kepanggang Wirang Tiwiek SA and Implikasinya dalam Pembelajaran Bahasa Jawa di SMA.

Lingua, (2017), 14(2): 155 180.

"Aduh Plo, Gemplo! Bodhomu iku lho kok ra entek-entek. Tujuwane awake dhewe mrene iki rak nglari buron aran Wirastri. Gek manut informasi wonge bukak warung Jawa. Lho, sapa ngerti olehe bukak neng lingkup terminal kene.

Rak kari ndhekep ora sah repot-repot!" (Tiwiek SA, 2016: 147)

\title{
Terjemahan:
}

"Aduh Plo, Gemplo! Kamu itu bodoh sekali. Tujuan kita kesini kan mencari buronan yang bernama Wirastri. Dan menurut informasi dia buka warung Jawa. Lho, siapa tau dia buka warung di lingkungan terminal sini. Kan tinggal nangkap tidak perlu repot-repot!" (Tiwiek SA, 2016: 147)

\begin{abstract}
Alur
Kepanggang Wirang menceritakan kehidupan keluarga Joni Kismanto yang mengalami perceraian dikarenakan adanya orang ketiga yang tidak lain adalah Suminingrum mantan kekasih Joni Kismanto semasa duduk di bangku SMA. Alur cerita yang ditampilkan pada novel ini merupakan alur campuran. Pada awal cerita ditampilkan pertikaian antara perempuan bertopeng hitam di ruangan kerja Joni Kismanto yang menyebabkan Joni Kismanto cacat dan juga kejadian di rumah Joni Kismanto yang dilakukan seorang bertopeng hitam yang menyebabkan bibir Suminingrum robek. Berikut kutipannya:

"Joni Kismanto! Tekaku mrene arep nantang kowe! Ora nantang adu kaculikan koyo patrapmu. Ning nantang adu karosan! Ayo tuduhno olehmu lanang. Aja mung pinter pasang paeka lan culika kaya sing koktindhakake marang tilas bojomu! Kowe ya kudu pinter kridhaning yudha!" (Tiwiek SA, 2016: 2)
\end{abstract}

\section{Terjemahan:}

"Joni Kismanto! Kedatanganku disini menantang kamu! Bukan menantang adu kelicikan seperti kamu. Tapi adu kekuatan! Ayo tunjukkan kejantananmu. Jangan hanya pandai pasang dan kelicikan seperti yang kamu lakukan terhadap mantan istrimu! Kamu juga harus pandai bela diri!" (Tiwiek SA, 2016: 2)

Selanjutnya ditampilkan tokoh pembantu yang memiliki keterkaitan cerita selanjutnya. Kepanggang Wirang juga menampilkan cerita flash back yang memiliki keterkaitan dengan konflik dalam cerita tersebut yaitu Ketika Joni Kismanto pulang ke Solo untuk menjenguk ibu kandungnya yang sedang sakit. Ketika di Solo Joni Kismanto bertemu dengan teman lamanya dan menceritakan tentang keadaan Suminingrum yang telah menjadi janda. Berikut ini kutipannya:

"O iya Dhik. Ningrum saiki warandha lho. Mentas ditinggal seda kakunge. Sprene wes karotengah taun.” (Tiwiek SA, 2016: 16)

\section{Terjemahan:}

"O iya Dhik. Ningrum sekarang menjanda lho. Setelah suaminya meninggal. Sekitar satu setengah tahun yang lalu." (Tiwiek SA, 2016: 16) 
LINGUA, Vol. 14, No. 2, September 2017

p ISSN: 1979 9411; e ISSN: 2442 238X

Http://lingua.pusatbahasa.or.id; Email: presslingua@gmail.com

Center of Language and Culture Studies, Surakarta, Indonesia

Lanua, Maretin Ardile, Rhian; Saddhono, Kundharu \& Supana. 2017. Struktur Instrinsik

Novel Kepanggang Wirang Tiwiek SA and Implikasinya dalam Pembelajaran Bahasa Jawa di SMA. Lingua, (2017), 14(2): 155 180.

Setelah kejadian tersebut, mulai terjadi kerumitan pertikaian yang menjadi awal konflik dalam Kepanggang Wirang. Pertikaian terjadi pada tokoh utama, yaitu Joni Kismanto dan Wirastri. Sepulang dari Solo Joni Kismanto mulai berfikir bagaimana caranya agar dapat menceraikan Wirastri dan menikahi Suminingrum. Kemudian Joni Kismanto merancang sebuah rekayasa seolah-olah Wirastri yang melakukan kesalahan. Dengan dibantu teman-teman Joni Kismanto akhirnya Joni Kismanto berhasil menceraikan Wirastri dan tak lama kemudian dapat menikahi Suminingrum.

Konflik juga terjadi antara Joni Kismanto dengan kedua anaknya. Semenjak menikah dengan Suminingrum, sikap Joni Kismanto berubah kepada anak-anaknya. Terjadi kecemburuan dalam keluarga Joni Kismanto. Konflik juga terjadi pada Wirastri setelah bercerai dengan Joni Kismanto. Semenjak bercerai dia tidak tau arah tujuannya. Dia hanya memiliki rekan semasa kuliah dahulu yang berdomisili di Malang, dan itu menjadi satu-satunya tujuan Wirastri. Namun sesampainya di Malang ternyata temannya sudah tidak lagi tinggal di Malang. Wirastri mulai kebingungan dan konflik kembali terjadi ketika di terminal Malang Wirastri kecopetan. Kemudian datanglah Pak Made Tantra menolong Wirastri. Berikut kutipannya:

"Copet! Copet! Tulung...! tas kula dicopet tiyang klambi lorek nika!" Panguwuhe karo tuding-tuding. Aneh, wong-wong sing neng kono sajak ora mreduli karo panguwuhe Wirastri." (Tiwiek SA, 2016: 86)

\section{Terjemahan:}

"Copet! Copet! Tolong...! Tas saya dicopet orang berpakaian garis itu! Teriaknya sambil menunjuk orang yang dimaksud. Aneh, orang-orang yang disana seperti tidak memperdulikan teriakannya Wirastri." (Tiwiek SA, 2016: 86)

Akhirnya pada bagian ini terjadi anti klimaks untuk Wirastri ditandai dengan Pak Made Tantra menawarkan kepada Wirastri untuk tinggal bersamanya dan akan difasilitasi ruko milik Pak Made Tantra untuk usaha Wirastri selama di Bali. Wirastri juga mendapatkan pelajaran ilmu bela diri dari Pak Made Tantra yang memiliki pelatihan bela diri.

Konflik selanjutnya terjadi ketika Joni Kismanto mengetahui bahwa yang mencelakai dirinya dan Suminingrum adalah Wirastri, kemudian Joni Kismanto menyuruh anak buahnya untuk membalas dendam dengan Wirastri. Joni Kismanto menginginkan Wirastri mengalami nasib yang sama seperti dirinya dan Suminingrum seperti pada kutipan berikut ini:

"Iya, pancen mungsuhe bosku iki wong wadon. Iki mono biyen garwane bosku. Saiki wis dipegat. Bosku wis krama maneh. Sajake tilasane iki mrina. Nate teka neng kantor njur mrewasa bosku nganti saiki bosku impoten. Njur garwane bosku sing anyar diuntir lambene nganti dawir. Mulane bosku dhendam njur pengin males wirang kanthi nyambat kowe kuwi." (Tiwiek SA, 2016: 142)

\section{Terjemahan:}


LINGUA, Vol. 14, No. 2, September 2017

p ISSN: 1979 9411; e ISSN: 2442 238X

Http://lingua.pusatbahasa.or.id; Email: presslingua@gmail.com

Center of Language and Culture Studies, Surakarta, Indonesia

Lanua, Maretin Ardile, Rhian; Saddhono, Kundharu \& Supana. 2017. Struktur Instrinsik

Novel Kepanggang Wirang Tiwiek SA and Implikasinya dalam Pembelajaran Bahasa Jawa di SMA.

Lingua, (2017), 14(2): 155 180.

"Iya, memang musuh bosku ini seorang perempuan. Ini dulu istrinya bosku. Sekarang sudah diceraikan. Bosku sudah menikah lagi. Sepertinya mantannya tidak terima. Kemudian datang ke kantor lalu mencelakai bosku hingga impoten. Dan kemudian istri barunya bosku bibirnya diputar hingga robek. Makanya bosku dendam kemudian ingin balas dendam dengan minta bantuan kamu itu." (Tiwiek SA, 2016: 142)

Klimaks terjadi ketika kedua anak buah Joni Kismanto telah berhasil menemukan keberadaan Wirastri di Bali. Merasa targetnya seorang perempuan, Dhugel dan Gemplo menganggap remeh Wirastri. Dengan modus sebagai kerabatnya dari Tulungagung memberi kabar bahwa orang tua Wirastri sakit. Namun disini Wirastri sedikit curiga karena ketika dia pulang ke rumah orang tuanya merasa tidak memberikan alamat lengkap dimana dia tinggal. Ketika Pak Made Tantra keluar dari kamar Wirastri ternyata Dhugel dan Gemplo sudah berada di depan kamar Wirastri dan bermaksud ingin mencelakainya. Namun salah, Pak Made Tantra dan Wirastri jauh lebih pandai dalam bidang bela diri sehingga membuat Dhugel dan Gemplo kalah. Berikut kutipannya:

"Dhugel apadene Gemplo rumangsa kecelik. Sakawit dheweke ngira, sektiya kaya apa yen jeneng wong wadon genah kemrubyuk kabotan pinjung. Mesti gampang dikalahke. Ning nyatane, malah Dhugel sing ketleyek. Dheweke ngrasa manawa Wirastri dudu mungsuhe." (Tiwiek SA, 2016: 156)

\section{Terjemahan:}

"Dhugel dan Gemplo merasa tertipu. Sebelumnya dia mengira, sesakti apapun seorang perempuan pasti gampang dikalahkan. Tapi kenyataannya berbeda, Dhugel yang kalah. Dirinya merasa Wirastri bukan tandingannya." (Tiwiek SA, 2016: 156)

Bagian ini merupakan puncak klimaks, yaitu ketika Dhugel dan Gemplo berhasil dikalahkan oleh Wirastri, kemudian Wirastri mengambil kesempatan dengan menanyai siapa yang menyuruhnya untuk mencelakai Wirastri.

Akhir dari cerita ini adalah ketika Joni Kismanto ditelpon Suminingrum untuk segera pulang. Sesampainya di rumah Joni Kismanto kaget ketika melihat Wirastri datang dengan membawa dua anak buah suruhannya yang kalah melawan Wirastri. Kemudian Joni Kismanto meminta maaf kepada Wirastri dan membuat surat pernyataan untuk tidak mengulangi perbuatannya dan menyerahkan kedua anaknya untuk ikut bersama Wirastri. Hal tersebut dapat dilihat dari kutipan berikut ini:

"Isine prajanjen iki nyebutake manawa muncule kadurakan iki sing ndhalangi lan sing ngrekayasa panjenengan. Njur sing kapindho, panjenengan kudu ngrilakake Pujilestari lan Dwi Saksono melu aku. Mung wae panjenengan sing kajibah ngragadi sekolahe lan kabutuhan saben dinane nganti bocah loro mentas. Sing 
LINGUA, Vol. 14, No. 2, September 2017

p ISSN: 1979 9411; e ISSN: 2442 238X

Http://lingua.pusatbahasa.or.id; Email: presslingua@gmail.com

Center of Language and Culture Studies, Surakarta, Indonesia

Lanua, Maretin Ardile, Rhian; Saddhono, Kundharu \& Supana. 2017. Struktur Instrinsik

Novel Kepanggang Wirang Tiwiek SA and Implikasinya dalam Pembelajaran Bahasa Jawa di SMA.

Lingua, (2017), 14(2): 155 180.

pungkasan, panjenengan kudu sumpah sumedya dadi wong becik." (Tiwiek SA, 2016: 165)

\section{Terjemahan:}

"Isi dari perjanjian ini menyebutkan bahwa munculnya tindak kejahatan ini yang mendalangi dan merekayasa anda. Kemudian yang kedua, anda harus merelakan Pujilestari dan Dwi Saksono ikut dengan saya. Hanya saja anda yang bertugas membiayai sekolah dan kebutuhan sehari-hari hingga dua anak itu menikah. Yang terakhir, anda harus bersumpah bersedia menjadi orang baik." (Tiwiek SA, 2016: 165)

\section{Latar/ Setting}

\section{a. Latar Tempat}

Kepanggang Wirang memiliki banyak latar yang mendukung jalannya cerita dalam novel tersebut. Berikut urutan latar dalam Kepanggang Wirang.

\section{1) Bank Dana Arta}

Bank Dana Arta merupakan tempat dimana Joni Kismanto bekerja sebagai kepala cabang Bank Dana Arta bertempat di kota Kediri. Berikut ini kutipannya:

"Wektu semono Bank Dana Arta cabang Kediri kuwi lagi wae madeg. Lan Joni Kismanto minangka pimpinane." (Tiwiek SA, 2016: 140)

\section{Terjemahan:}

"Waktu itu Bank Dana Arta cabang Kediri baru saja berdiri. Dan Joni Kismanto sebagai pimpinannya." (Tiwiek SA, 2016: 140)

\section{2) Rumah Joni Kismanto}

Rumah Joni Kismanto dalam Kepanggang Wirang digambarkan sebagai rumah mewah yang memiliki pagar besi yang terletak di jalan Daha. Berikut kutipannya:

"Ana becak mandheg neng sangarepe omah mewah mawa pager wesi, ing jalan Daha." (Tiwiek SA, 2016: 4)

\section{Terjemahan:}

"Ada becak berhenti di depan rumah mewah dengan pagar besi, di jalan Daha." (Tiwiek Sa, 2016: 4)

\section{3) Terminal}

Terminal merupakan salah satu setting tempat dimana Wirastri mengalami kecopetan ketika Wirastri mengalami kebingungan karena tidak tau kemana dia harus pergi. Ketika kecopetan Wirastri ditolong oleh Pak Made Tantra dan menawarkan kepada Wirastri untuk tinggal bersamanya. Berikut kutipannya:

"Anggone lenger-lenger neng terminal nganti wengi. Tarah budhale saka Kediri pancen wis awan. Lan anggone nggoleki alamate kancane ya nganti suwe. 
LINGUA, Vol. 14, No. 2, September 2017

p ISSN: 1979 9411; e ISSN: 2442 238X

Http://lingua.pusatbahasa.or.id; Email: presslingua@gmail.com

Center of Language and Culture Studies, Surakarta, Indonesia

Lanua, Maretin Ardile, Rhian; Saddhono, Kundharu \& Supana. 2017. Struktur Instrinsik

Novel Kepanggang Wirang Tiwiek SA and Implikasinya dalam Pembelajaran Bahasa Jawa di SMA.

Lingua, (2017), 14(2): 155 180.

Ewadene Wirastri durung pengen menyat saka lungguhe. Sajak krenegen njedhodhot kanthi polatan pupus lan pepes. Embuh wis pira wae cacahe bis sing teka lan lunga ing terminal kono. Wirastri sajak ora preduli." (Tiwiek SA, 2016: 85)

\section{Terjemahan:}

"Dia duduk di terminal hingga malam. Berangkatnya dari Kediri memang sudah siang. Dan ketika mencari alamat rumah temannya juga hingga sampai sore. Wirastri enggan pergi dari tempat duduknya. Seperti sudah tidak ada harapan. Tidak tahu berapapun bis yang datang dan pergi di terminal itu. Wirastri tidak peduli." (Tiwiek SA, 2016: 85)

\section{4) Rumah Pradopo}

Rumah Pradopo terletak di jalan Mawar nomor 45D. Pengarang menggambarkan rumah Pradopo sebagai setting tempat dengan model rumah tua yang tidak terawat dengan ditumbuhi rumput yang sangat lebat. Hal ini disesuaikan dengan kondisi Pradopo yang pengangguran dan tidak memiliki keluarga. Seperti pada kutipan berikut ini:

"Omah kui modhel lawas. Sajak ora kopen. Latare njembrung, sukete lemu-lemu. Dhasar manggon neng ngisor wit sawo kang nyrembuyung." (Tiwiek SA, 2016: 93)

\section{Terjemahan:}

"Rumah itu model lama. Seperti tidak terawat. Halamannya sangat kotor, ditumbuhi rumput yang sangat lebat. Bertempat di bawah pohon sawo yang lebat." (Tiwiek SA, 2016: 93)

\section{5) Rumah Makan Miraos}

Rumah Makan Miraos merupakan rumah makan milik Wirastri di Bali. Rumah makan tersebut menyediakan berbagai masakan Jawa. Pengarang menggambarkan rumah makan tersebut seperti restoran mewah dengan banyak pegawai di dalamnya. Hal ini menggambarkan usaha Wirastri sukses setelah bercerai dari Joni Kismanto. Seperti pada kutipan berikut ini:

"Ing wayah jam semono mau warung Miraos katon rame. Pengunjunge akeh. Sing akeh ya wong Jawa sing durung kulina karo mangsakan Bali." (Tiwiek SA, 2016: 151)

\section{Terjemahan:}

"Pada waktu itu warung Miraos terlihat ramai. Pengunjungnya banyak. Kebanyakan orang Jawa yang belum terbiasa dengan masakan Bali." (Tiwiek SA, 2016: 151) 
LINGUA, Vol. 14, No. 2, September 2017

p ISSN: 1979 9411; e ISSN: 2442 238X

Http://lingua.pusatbahasa.or.id; Email: presslingua@gmail.com

Center of Language and Culture Studies, Surakarta, Indonesia

Lanua, Maretin Ardile, Rhian; Saddhono, Kundharu \& Supana. 2017. Struktur Instrinsik

Novel Kepanggang Wirang Tiwiek SA and Implikasinya dalam Pembelajaran Bahasa Jawa di SMA.

Lingua, (2017), 14(2): 155 180.

\section{6) Rumah Made Tantra}

Rumah Made Tantra terletak di jalan Nangka. Rumah tersebut digambarkan rumah sederhana. Rumah Made Tantra dihuni tiga orang, yaitu Made Tantra, istrinya dan Wirastri. Rumah Made Tantra dijadikan pengarang sebagai setting tempat ketika klimaks dalam cerita memuncak. Berikut kutipannya:

"Ing salah sawijining omah prasaja kang dhumunung ing jalan Nangka, mobil Suzuki Carry mandheg. Lawang sopiran menga. Wirastri mudhun bablas ngener lawang ngarep. Dene mobile suzuki iku bablas mlebu garasi ing ngiringan omah." (Tiwiek SA, 2016: 153)

\section{Terjemahan:}

"Pada salah satu rumah sederhana yang terletak di jalan Nangka, mobil Suzuki Carry berhenti. Pintu kemudi terbuka. Wirastri turun langsung menuju pintu depan. Sedangkan mobil suzuki langsung menuju garasi yang terletak di samping rumah." (Tiwiek SA, 2016: 153)

\section{b. Latar Waktu}

Latar waktu merupakan waktu kejadian-kejadian yang terjadi dalam sebuah cerita fiksi. Latar waktu dapat berupa waktu-waktu tertentu (hari, bulan, tahun, jam, cuaca, dan satu periode sejarah). Berikut contoh kutipan untuk latar waktu.

\section{1) Siang Hari}

Pada hari yang sama pada waktu siang hari seorang wanita turun dari becak mengenakan pakaian serba hitam turun di dekat rumah Joni Kismanto. Berikut kutipannya:

"Iseh ing dina iku. Mung wektune rada awan sithik. Ana becak mendheg neng sangarepe omah mewah mawa pager wesi ing jalan Daha. Penumpange mudhun. Saweneh wanita ayu umur watara patang puluhan. Nganggo clana ketat rupa ireng, kaos lengen dawa uga rupa ireng." (Tiwiek SA, 2016: 4)

\section{Terjemahan:}

"Masih di hari yang sama. Hanya saja sedikit siang. Ada becak berhenti di depan rumah mewah berpagar besi di jalan Daha. Penumpangnya turun. Terlihat seorang wanita cantik berumur sekitar empat puluh tahunan. Mengenakan celana ketat warna hitam, kaos lengan panjang juga warna hitam.” (Tiwiek SA, 2016: 4)

\section{2) Sembilan Bulan yang Lalu}

Sembilan bulan yang lalu, Joni Kismanto pulang ke rumah orang tuannya di Solo karena mendapat kabar bahwa orang tuanya sakit. Ketika di Solo Joni Kismanto mendapat berita tentang Suminingrum yang telah menjadi janda karena ditinggil mati suaminya. Berikut kutipannya:

"Sangang sasi kepungkur, Joni Kismanto tilik wong tuwane ing Sala. Awit oleh kabar manawa wong tuwane gerah. Sasuwene omah dhewe ing Kediri, apa 
LINGUA, Vol. 14, No. 2, September 2017

p ISSN: 1979 9411; e ISSN: 2442 238X

Http://lingua.pusatbahasa.or.id; Email: presslingua@gmail.com

Center of Language and Culture Studies, Surakarta, Indonesia

Lanua, Maretin Ardile, Rhian; Saddhono, Kundharu \& Supana. 2017. Struktur Instrinsik

Novel Kepanggang Wirang Tiwiek SA and Implikasinya dalam Pembelajaran Bahasa Jawa di SMA.

Lingua, (2017), 14(2): 155 180.

maneh sawise njabat pimpinan Bank Dana Arta, Joni pancen arang banget tilik wong tuwane." (Tiwiek SA, 2016: 14)

\section{Terjemahan:}

"Sembilan bulan yang lalu, Joni Kismanto menjenguk orang tuanya di Solo. Karena mendapat berita bahwa orang tuanya sakit. Selama tinggal di Kediri, apalagi setelah menjabat pimpinan Bank Dana Arta, Joni jarang menjenguk orang tuanya." (Tiwiek SA, 2016: 14)

\section{3) Hari Jumat Sore}

Para karyawan Bank Dana Arta sudah pada pulang, tinggal penjaga kantor dan Joni Kismanto yang masih di kantor. Joni Kismanto masih menerima tamu di ruangannya. Hal tersebut tampak pada kutipan berikut ini:

"Dina Jemuwah sore ing kantor Bank Dana Arta. Wayahe wis kliwat jam papat. Kantor bank kui wis sepi. Awit temene wis tutup. Para karyawan wis padha mulih. Sing isih janggrung mung penjaga kantor. Batine ya ngresula, awit kancakancane wis padha bubar. Dheweke kepeksa keri awit pimpinan bank kasebut, si Joni Kismanto, durung kondur.” (Tiwiek SA, 2016: 30)

\section{Terjemahan:}

"Hari Jumat sore di kantor Bank Dana Arta. Waktu sudah lewat jam empat. Kantor bank itu sudah sepi. Karena sudah tutup. Para karyawan sudah pulang. Yang masih tinggal penjaga kantor. Dalam hatinya juga menggerutu, karena rekan-rekannya sudah pulang. Dirinya terpaksa tinggal karena pimpinan bank tersebut, si Joni Kismanto, belum pulang." (Tiwiek SA, 2016: 30)

\section{4) Senin Pagi}

Seperti pagi-pagi biasanya, Joni Kismanto bersiap untuk berangkat ke kantor, namun sedikit berbeda, biasanya Wirasrtri membantu memasangkan dasi, namun kali ini Joni Kismanto menolak untuk dibantu. Berikut kutipannya.

"Dina Senen esuk, Joni Kismanto wis macak mlipis. Siyaga budhal ngantor. Biyasane Wirastri mbantu masang dhasi, nalekake sepatu. Ning sepisan iki sajake Joni ora butuh bantuwanne sisihane. Nalika Wirastri kumplawe arep masang dhasi, tanganne ditampel." (Tiwiek SA, 2016: 31)

\section{Terjemahan:}

"Hari senin pagi, Joni Kismanto sudah rapi. Siap berangkat ngantor. Biasanya Wirastri membantu memasang dasi, mengikat tali sepatu. Namun kali ini Joni tidak butuh bantuan istrinya. Ketika Wirastri hendak memasangkan dasi, tangannya di tolak." (Tiwiek SA, 2016: 31) 
LINGUA, Vol. 14, No. 2, September 2017

p ISSN: 1979 9411; e ISSN: 2442 238X

Http://lingua.pusatbahasa.or.id; Email: presslingua@gmail.com

Center of Language and Culture Studies, Surakarta, Indonesia

Lanua, Maretin Ardile, Rhian; Saddhono, Kundharu \& Supana. 2017. Struktur Instrinsik

Novel Kepanggang Wirang Tiwiek SA and Implikasinya dalam Pembelajaran Bahasa Jawa di SMA. Lingua, (2017), 14(2): 155 180.

\section{5) Jam Satu Lebih Tujuh Menit}

Pujilestari dan Dwi Saksono pulang dari sekolah. Seperti biasanya Mbok Tarminah membukakan pintu gerbang rumah sambil khawatir akan pertanyaan dari Pujilestari dan Dwi Saksono mengenai keberadaan ibunya. Berikut kutipannya:

"Jam siji punjul pitung menit Pujilestari lan Dwi Saksono teka saka sekolahan. Krang-kring ngunekke bel-e sepedhah neng ngarep regol. Mbok Tarminah gegancangan mbukak lawang regol. Ora wurung jantunge jumeglug luwih rosa." (Tiwiek SA, 2016: 41)

\section{Terjemahan:}

"Jam satu lebih tujuh menit Pujilestari dan Dwi Saksono datang dari sekolah. Krang-kring membunyikan bel sepeda di depan gerbang. Mbok Tarminah segera membukakan pintu gerbang. Disertai dengan jantung yang berdegup kencang." (Tiwiek SA, 2016: 41)

\section{Tema}

Menurut Waluyo (2011:7) tema adalah gagasan pokok dalam cerita fiksi. Untuk mengetahui tema dalam sebuah novel, pembaca tidak bisa mengetahuinya dengan melihat judul, tetapi diperlukan untuk membaca keseluruhan agar mengetahui isi cerita dan menemukan tema cerita. Cerita akan mengikuti gagasan dasar umum yang telah ditetapkan, sehingga berbagai peristiwa konflik, dan pemilihan berbagai unsur instrinsik yang lain akan mencerminkan gagasan dasar tersebut.

Tema yang diangkat dalam Kepanggang Wirang adalah problem keluarga. Novel banyak menceritakan tentang problem keluarga yang meliputi perselingkuhan dan perceraian. Tema problem keluarga ini menjadikan Kepanggang Wirang ini sangat menarik untuk dibaca.

Novel ini berkisah tentang tokoh Wirastri yang tidak terima karena telah ditiduri oleh lelaki yang tidak bertanggung jawab yang menjadikannya diceraikan suaminya, namun setelah terungkap semua ternyata dalang dari semua ini adalah sang suami yang bernama Joni Kismanto. Joni Kismanto melakukan ini semua karena dia bingung bagaimana caranya agar bisa menceraikan istrinya supaya bisa menikah lagi dengan mantan kekasihnya semasa sekolah dahulu.

\section{Sarana-Sarana Sastra}

Sarana-sarana sastra diartikan sebagai metode (pengarang) dalam memilih dan menyusun detail cerita agar dapat tercapai pola-pola yang bermakna. Metode ini dapat melihat berbagai fakta melalui kacamata pengarang, memahami apa maksud fakta-fakta tersebut sehingga pengalamanpun dapat dibagi. Sarana-sarana sastra dalam Kepanggang Wirang adalah sebagai berikut:

\section{1) Judul}

Judul novel untuk penelitian ini adalah Kepanggang Wirang. Judul ini memiliki arti terbakar malu. Judul ini digunakan karena sesuai dengan isi dari cerita novel 
LINGUA, Vol. 14, No. 2, September 2017

p ISSN: 1979 9411; e ISSN: 2442 238X

Http://lingua.pusatbahasa.or.id; Email: presslingua@gmail.com

Center of Language and Culture Studies, Surakarta, Indonesia

Lanua, Maretin Ardile, Rhian; Saddhono, Kundharu \& Supana. 2017. Struktur Instrinsik

Novel Kepanggang Wirang Tiwiek SA and Implikasinya dalam Pembelajaran Bahasa Jawa di SMA. Lingua, (2017), 14(2): 155 180.

tersebut, yaitu Joni Kismanto yang telah menceraikan istrinya yang bernama Wirastri dan menikah lagi dengan Suminingrum. Joni Kismanto mengatur siasat agar perceraiannya berjalan lancar, yaitu dengan membuat skenario seolah-olah Wirastri berselingkuh dengan lelaki lain.

Dendam Wirastri yang semula hanya kepada lelaki yang meniduri dirinya itu sekarang bertambah kepada Joni Kismanto dan istri barunya Suminingrum setelah mendapat informasi dari lelaki yang meniduri dirinya itu. Semua skenario Joni Kismanto terbongkar dan kini Joni Kismanto harus menanggung malu di hadapan Wirastri karena Wirastri telah berhasil membalas dendam kepada Joni Kismanto dengan membuat Joni Kismanto lumpuh sebagai seorang lelaki.

\section{2) Sudut Pandang}

Kepanggang Wirang menggunakan sudut pandang orang ketiga tak terbatas. Pengarang memposisikan diri sebagai orang ketiga. Pengarang seolah mengerti apa yang dirasakan tokoh dalam cerita tersebut. Hal ini sesuai dengan kutipan berikut ini:

"Dina Jemuwah sore ing kantor Bank Dana Arta. Wayahe wis kliwat jam papat.

Kantor bank kui wis sepi. Awit temene wis tutup. Para karyawan wis padha mulih. Sing isih janggrung mung penjaga kantor. Batine ya ngresula, awit kancakancane wis padha bubar. Dheweke kepeksa keri awit pimpinan bank kasebut, si Joni Kismanto, durung kondur." (Tiwiek SA, 2016: 30)

\section{Terjemahan:}

"Hari Jumat sore di kantor Bank Dana Arta. Waktu sudah lewat jam empat. Kantor bank itu sudah sepi. Karena sudah tutup. Para karyawan sudah pulang. Yang masih tinggal penjaga kantor. Dalam hatinya juga menggerutu, karena rekan-rekannya sudah pulang. Dirinya terpaksa tinggal karena pimpinan bank tersebut, si Joni Kismanto, belum pulang." (Tiwiek SA, 2016: 30)

Sudut pandang digambarkan melalui dua cara yaitu secara subjektif dan objektif. Penggambaran secara subjektif maksudnya adalah ketika pengarang langsung menilai dan menafsirkan karakter dalam cerita. Penggambaran objektif maksudnya ketika pengarang menghindari menampakkan gagasan-gagasan dan emosi-emosi. Pembacalah yang berhak memutuskan segalanya dari fakta-fakta tanpa bantuan dari siapapun.

Sudut pandang dalam Kepanggang Wirang menggunakan keduanya, yaitu secara subjektif dan objektif. Secara subjektif pengarang secara langsung menafsirkan berbagai karakter seakan pernah merasakannya. Secara objektif yaitu pengarang menampakkan karakter dalam cerita secara tidak langsung menafsirkan, yaitu melalui dialog-dialog yang ditampilkan sepanjang cerita.

\section{Gaya dan Tone}

Gaya adalah cara pengarang menggunakan bahasa. Gaya bisa berkaitan dengan maksud dan tujuan cerita. Meski dua orang pengarang memakai alur, karakter, dan latar yang sama, hasil tulisan keduanya bisa sangat berbeda. Perbedaan tersebut secara umum 
LINGUA, Vol. 14, No. 2, September 2017

p ISSN: 1979 9411; e ISSN: 2442 238X

Http://lingua.pusatbahasa.or.id; Email: presslingua@gmail.com

Center of Language and Culture Studies, Surakarta, Indonesia

Lanua, Maretin Ardile, Rhian; Saddhono, Kundharu \& Supana. 2017. Struktur Instrinsik

Novel Kepanggang Wirang Tiwiek SA and Implikasinya dalam Pembelajaran Bahasa Jawa di SMA. Lingua, (2017), 14(2): 155 180.

terletak pada bahasa dan menyebar dalam berbagai aspek seperti kerumitan, ritme, panjang-pendek kalimat, detil, humor, kekonkretan, dan banyaknya imaji dan metafora. Kepanggang Wirang menggunakan gaya misterius dan gaya heroik. Gaya misterius terlihat dari kutipan berikut ini:

"Nalika tumenga, dudu Erni sing katon. Nanging saweneh pawongan sing babarpisan durung ditepungi. Kepriye olehe arep nepungi. Awit pawongan iku nganggo tutup rai neru ninja ngana kae. Semono uga panganggo liyane. Clana singset ireng sarta kaos lengen dawa rupa ireng uga." (Tiwiek SA, 2016: 1)

\section{Terjemahan:}

"Ketika menengok, bukan Erni yang terlihat. Namun nampak seseorang yang sama sekali belum pernah dikenal. Bagaimana mau kenal. Karena orang itu menggunakan tutup wajah seperti ninja. Begitu juga pakaian lainnya. Celana ketat warna hitam serta kaos lengan panjang juga warna hitam.” (Tiwiek SA, 2016: 1)

\section{1) Simbolisme}

Simbolisme merupakan detail-detail konkret dan faktual dan memiliki kemampuan untuk memunculkan gagasan dan emosi dalam pikiran pembaca. Simbol dapat berwujud apa saja, dari sebutir telur hingga latar cerita seperti satu objek, beberapa objek bertipe sama, substansi fisis, bentuk, gerakan, warna, suara, atau keharuman. Semua hal tersebut dapat menghadirkan satu fakta terkait kepribadian seorang manusia, ketidakacuhan alam terhadap penderitaan manusia, ambisi yang semu, kewajiban manusia, atau romantisme masa muda.

Simbol dalam Kepanggang Wirang yaitu pada saat bagian saat Joni Kismanto mendapat kabar bahwa Suminingrum telah menjadi seorang janda setelah ditinggal mati suaminya. Pada saat itu rasa sayang dari Joni Kismanto kepada Suminingrum yang diibaratkan cacing kremi yang telah mati kembali hidup di benaknya. Hal tersebut tampak pada kutipan berikut ini:

"Ah, kremi sing wis mati iku dumadakan urip maneh. Citrane Suminingrum sing ayu bali kumlebet ing angen-angen." (Tiwiek SA, 2016: 22)

\section{Terjemahan:}

"Ah, kremi yang sudah mati itu tiba-tiba hidup lagi. Wajah Suminingrum yang cantik kembali masuk di angan-angan." (Tiwiek SA, 2016: 22)

\section{2) Ironi}

Ironi dimaksudkan sebagai cara untuk menunjukkan sesuatu yang berlawanan dengan dugaan sebelumnya. Terdapat dua jenis ironi dalam cerita fiksi yaitu 'ironi dramatis' dan 'tone ironis' atau 'ironi verbal'. Ironi dramatis atau ironi alur dan situasi biasanya muncul melalui kontras diametrik antara penampilan dan realitas, antara maksud dan tujuan seorang karakter dengan apa yang sebenarnya terjadi. Ironi dalam Kepanggang Wirang terdapat pada saat Dugel dan Gemplo ingin menculik Wirastri. Dhugel dan Gemplo menganggap remeh dengan kekuatan seorang perempuan, namun 
LINGUA, Vol. 14, No. 2, September 2017

p ISSN: 1979 9411; e ISSN: 2442 238X

Http://lingua.pusatbahasa.or.id; Email: presslingua@gmail.com

Center of Language and Culture Studies, Surakarta, Indonesia

Lanua, Maretin Ardile, Rhian; Saddhono, Kundharu \& Supana. 2017. Struktur Instrinsik

Novel Kepanggang Wirang Tiwiek SA and Implikasinya dalam Pembelajaran Bahasa Jawa di SMA. Lingua, (2017), 14(2): 155 180.

setelah melihat keahlian Wirastri dalam bela diri, Dhugel dan Gemplo kaget. Hal ini terdapat pada kutipan berikut ini:

"Ing batin Dhugel ora percaya. Kok wong wadon iku kekuwatane ngedap-edabi?

Katone mung kumlawe satitahe, nanging akibate nggegirisi. Nyatane Dhugel

sing awake methekel nganti tiba kejengkang." (Tiwiek SA, 2016: 155)

\section{Terjemahan:}

"Dalam hatinya Dhugel tidak percaya. Perempuan itu kekuatannya luar biasa.

Terlihat hanya bergerak seperti biasa, namun akibatnya fatal. Kenyataannya

Dhugel yang berbadan besar jatuh hingga terperosok." (Tiwiek SA, 2016: 155)

"Tone ironi" atau "ironi verbal" digunakan untuk menyebut cara berekspresi yang mengungkapkan makna dengan cara yang berlebihan. Dalam Kepanggang Wirang, ironi verbal ditemukan dalam kutipan berikut ini:

"Tas plastik ing tangane dibukak. Krudung ireng sing wis dicawisake dijupuk. Njur dienggo, kanthi mblusukake ing sirahe. Krudung kuwi dientra kaya sawal bantal, sing ana bolongane loro pas mripat. Dadi nganggone cepet. Saiki identitase Wirastri ora katon. Sing katon malih sawijining pawongan medeni memper tokoh gerombolan ing film kriminal." (Tiwiek SA, 2016: 95)

\section{Terjemahan:}

"Tas plastik di tangannya dibuka. Kerudung hitam yang sudah disiapkan diambil. Kemudian dipakai, dengan memasukkan kepalanya. Kerudung itu dibuat seperti sarung bantal, yang memiliki dua lubang tepat di bagian mata. Jadi cepat memakainya. Sekarang identitas Wirastri tidak terlihat. Yang terlihat berubah menjadi seorang yang menyeramkan seperti sekelompok orang dalam film kriminal." (Tiwiek SA, 2016: 95)

\section{Relevansi Terhadap Pembelajaran Bahasa Jawa di SMA}

Pembelajaran bahasa Jawa diarahkan untuk meningkatkan kemampuan peserta didik untuk dapat memahami dan berkomunikasi menggunakan bahasa Jawa dengan baik dan benar, baik secara lisan maupun tulisan, serta menumbuhkan apresiasi terhadap karya sastra Jawa. Pembelajaran yang demikian tersebut disusun pula dengan cara disesuaikan dengan kurikulum yang digunakan di SMA Negeri 1 Andong Boyolali, yaitu kurikulum 2013. Kurikulum 2013 merupakan kurikulum yang berbasis kompetensi yang dirancang untuk mengantisipasi kebutuhan kompetensi masa kini. Pada masa ini komunikasi dan kreativitas sangatlah dibutuhkan. Atas dasar itu, maka rumusan kompetensi sikap, kreativitas dan pengetahuan dipergunakan dalam kurikulum ini hal tersebut tercantum dalam silabus.

Pengembangan kurikulum yang diterapkan dalam kurikulum 2013 mengacu pada Kompetensi Inti (KI) dan Kompetensi Dasar (KD) yang terdapat pada kompetensi sikap (attitude), keterampilan (skill) dan pengetahuan (knowledge). Silabus merupakan penjabaran Kompetensi Inti dan Kompetensi Dasar ke dalam materi pokok 
LINGUA, Vol. 14, No. 2, September 2017

p ISSN: 1979 9411; e ISSN: 2442 238X

Http://lingua.pusatbahasa.or.id; Email: presslingua@gmail.com

Center of Language and Culture Studies, Surakarta, Indonesia

Lanua, Maretin Ardile, Rhian; Saddhono, Kundharu \& Supana. 2017. Struktur Instrinsik

Novel Kepanggang Wirang Tiwiek SA and Implikasinya dalam Pembelajaran Bahasa Jawa di SMA. Lingua, (2017), 14(2): 155 180.

pembelajaran, kegiatan pembelajaran dan indikator pencapaian kompetensi untuk penilaian.

Konsep tersebut memberikan peluang sekolah merumuskan dan menyusun silabusnya. Tetapi tidak berarti Kurikulum 2013 menekankan hanya pada pencapaian tujuan pendidikan saja. Penekanan tersebut berlaku pada standar kompetensi. Pemerintah memberikan peraturan untuk menyusun materi pembelajaran sedangkan guru menentukan silabus yang sesuai dengan kebutuhan dan karakter sekolah. Dengan demikian, guru dan sekolah diberikan kebebasan untuk menjabarkan materi dan mengembangkan indikator-indikator sehingga materi yang diajarkan selaras dengan karakteristik siswa dan potensi daerah setempat dengan tetap mempertimbangkan peraturan pemerintah. Dari sini maka guru dituntut untuk memahami kurikulum dan mampu menyajikan bahan pembelajaran yang menarik minat peserta didik.

Kurikulum 2013 untuk bahasa Jawa di SMA mencantumkan apresiasi novel Jawa berupa petikan teks novel Jawa sebagai materi pembelajaran kelas XI semester gasal. Siswa dituntut untuk menganalisis unsur pembangun novel dan nilai-nilai pitutur luhur. Penjelasannya, siswa tidak hanya mampu menjelaskan petikan novel tetapi siswa mampu memahami nilai-nilai budi pekerti yang terdapat di dalamnya. Pada bagian materi ajar, guru diberi kebebasan untuk menentukan bahan ajar yang berkualitas, sesuai dengan kebutuhan siswa dan mampu menjadi sarana penanaman nilai pendidikan budi pekerti. Nilai pendidikan moral merupakan salah satu bagian dari nilai pendidikan budi pekerti yang dapat dipelajari siswa dalam membaca novel. Nilai pendidikan moral dalam novel Kepanggang Wirang karya Tiwiek SA dapat menjadi contoh oleh peserta didik dalam kehidupan sehari-hari.

Kelas XI semester ganjil Kompetensi inti 3 yaitu Kompetensi Dasar pengetahuan memahami, menerapkan, menganalisis, dan mengevaluasi pengetahuan faktual, konseptual, presedural, dan metakognitif berdasarkan rasa ingin tahunya tentang ilmu pengetahuan, teknologi, seni, budaya, dan humaniora dengan wawasan kemanusiaan, keangsaan, kenegaraan, dan peradaban terkait penyebab fenomena dan kejadian, serta menerapkan pengetahuan prosedural pada bidang kajian yang spesifik sesuai dengan bakat dan minatnya untuk memecahkan masalah.

Novel Kepanggang Wirang karya Tiwiek SA dapat dijadikan sebagai novel yang dapat dianalisis siswa. Novel ini dapat disampaikan dengan media cetak berupa sinopsis novel Kepanggang Wirang. Dengan membaca sinopsis, siswa dapat menganalisis unsurunsur pembangun dan nilai pendidikan moral yang terdapat dalam novel Kepanggang Wirang karya Tiwiek SA. Analisis unsur-unsur pembangun dapat dideskripsikan dalam kajian berikut ini: 1) tema, 2) alur, 3) latar, 4) sudut pandang, 5) penokohan, 6) amanat dan 7) nilai pendidikan moral dalam novel Kepanggang Wirang karya Tiwiek SA.

Hal tersebut sesuai dengan pendapat Ikke Kusumawati (Guru Bahasa Jawa SMA Negeri 1 Andong Boyolali) yang menyatakan bahwa novel Kepanggang Wirang karya Tiwiek SA merupakan novel yang dapat dijadikan sebagai bahan ajar siswa kelas XI pada semester gasal. Novel tersebut menggunakan bahasa yang mudah dipahami peserta didik walaupun terdapat cuplikan adegan yang kurang pantas untuk dibaca peserta didik yang berusia di bawah 17 tahun dan ada beberapa kata yang tentunya kurang dipahami 
LINGUA, Vol. 14, No. 2, September 2017

p ISSN: 1979 9411; e ISSN: 2442 238X

Http://lingua.pusatbahasa.or.id; Email: presslingua@gmail.com

Center of Language and Culture Studies, Surakarta, Indonesia

Lanua, Maretin Ardile, Rhian; Saddhono, Kundharu \& Supana. 2017. Struktur Instrinsik

Novel Kepanggang Wirang Tiwiek SA and Implikasinya dalam Pembelajaran Bahasa Jawa di SMA. Lingua, (2017), 14(2): 155 180.

peserta didik, namun hal tersebut dapat dijelaskan pada kegiatan belajar mengajar. Selain itu novel Kepanggang Wirang karya Tiwiek SA juga memiliki unsur pembangun yang sangat jelas. Siswa dapat menganalisis unsur-unsur intrinsik yang terdapat dalam novel Kepanggang Wirang karya Tiwiek SA dan juga dapat menganalisis nilai pendidikan moral yang terdapat dalam novel Kepanggang Wirang karya Tiwiek SA untuk dapat diterapkan dalam kehidupan sehari-hari peserta didik.

Berdasarkan hasil dari angket yang dibagikan kepada siswa, novel Kepanggang Wirang karya Tiwiek SA relevan untuk dijadikan bahan ajar mata pelajaran bahasa Jawa di SMA. Dalam Kurikulum 2013 bahasa Jawa kelas XI SMA mencantumkan apresiasi novel Jawa berupa petikan teks novel Jawa sebagai materi pembelajaran kelas XI semester gasal.Siswa dituntut untuk dapat menganalisis unsur pembangun novel dan nilai-nilai pitutur luhur. Berdasarkan hasil dari angket, siswa mampu menganalisis unsur pembangun novel yang berupa unsur instrinsik. Siswa juga mampu menganalisis nilai-nilai pitutur luhur dalam hal ini berupa nilai pendidikan moral yang dapat dipetik setelah membaca novel tersebut.

Berdasarkan uraian di atas dapat disimpulkan bahwa novel Kepanggang Wirang karya Tiwiek SA dapat dijadikan materi ajar siswa kelas XI di SMA. Hal tersebut dikarenakan novel Kepanggang Wirang karya Tiwiek SA mengandung unsur-unsur pembangun dan nilai pendidikan moral yang dapat dipahami dan diterapkan siswa dalam kehidupan sehari-hari. Dengan demikian Kompetensi Inti mata pelajaran Bahasa Jawa yang meliputi kompetensi dasar seperti telah diuraikan di atas, guru dapat merelevankan antara materi yang akan diajarkan kepada peserta didiknya terhadap kompetensi dasar yang diinginkan dalam Kompetensi Inti.

\section{SIMPULAN}

Pola struktural novel Kepanggang Wirang karya Tiwiek SA menunjukkan unsur instrinsik pembangun cerita terdiri dari fakta-fakta cerita (karakter, alur latar), tema, dan sarana-sarana cerita (judul, sudut pandang, gaya dan tone, simbolisme, dan ironi). Tema yang berkaitan dengan kekerasan, kesenjangan sosial dan asmara sangat sering dijumpai di lingkungan masyarakat.

Novel Kepanggang Wirang karya Tiwiek SA memiliki karakter yang beragam, yaitu: pimpinan, petugas keamanan, pengangguran, ibu rumah tangga. Alur yang dipakai merupakan alur maju mundur. Pada episode tiga menggunakan alur mundur. Pada episode empat hingga dua puluh tiga menggunakan alur maju. Pengarang sengaja menaruh konflik pada bagian awal yang bertujuan untuk menarik pembaca untuk membaca hingga akhir episode.

Latar dalam novel Kepanggang Wirang karya Tiwiek SA mengambil daerah Kediri, Tulungagung dan Bali. Dari setting ini pengarang menampilkan kejadiankejadian yang mencolok dengan penggambaran yang jelas sehingga pembaca dapat mengimajinasikan dengan jelas. Secara keseluruhan unsur yang terdiri dari fakta-fakta cerita (karakter, alur, latar), tema, dan sarana-sarana cerita (judul, sudut pandang, gaya dan tone, simbolisme, dan ironi) memiliki keterkaitan satu dengan yang lain. 
LINGUA, Vol. 14, No. 2, September 2017

p ISSN: 1979 9411; e ISSN: 2442 238X

Http://lingua.pusatbahasa.or.id; Email: presslingua@gmail.com

Center of Language and Culture Studies, Surakarta, Indonesia

Lanua, Maretin Ardile, Rhian; Saddhono, Kundharu \& Supana. 2017. Struktur Instrinsik

Novel Kepanggang Wirang Tiwiek SA and Implikasinya dalam Pembelajaran Bahasa Jawa di SMA.

Lingua, (2017), 14(2): 155 180.

Keterkaitan antar unsur itu membuat suatu kesatuan yang utuh pada cerita dan membuat cerita lebih menarik.

\section{DAFTAR PUSTAKA}

Abu Hanafi dan Nur Uhbiyati. 1991. Ilmu Pendidikan. Jakarta: Qalbiymedia.

Adi, Ida Rochani. 2011. Fiksi Populer: Teori dan Metode Kajian. Yogyakarta: Pustaka Pelajar.

Atar Semi. 1993. Metode Penelitian Sastra. Bandung: Angkasa.

Burhanudin Nurgiyantoro. 2010. Teori Pengkajian Fiksi. Yogyakarta: Gadjah Mada University Press.

Globe, Frank G. 1987. Mahzab Ketiga: Psikologi Humanistik Abraham Maslow. Yogyakarta: Kanisius.

H.A Tilaar. 2000. Pendidikan Kebudayaan, dan Masyarakat Madani Indonesia. Bandung: Rosdakarya.

H.B. Sutopo. 2002. Metode Penelitian Kualitatif : Dasar Teori dan Penerapannya dalam Penelitian. Surakarta: UNS Press.

Hasbullah. 2005. Dasar-dasar Ilmu Pendidikan. Jakarta: Raja Grafindo Persada.

Heru Kurniawan. 2012. Teori, Metode, dan Aplikasi Sosiologi Sastra. Yogyakarta: Graha Ilmu.

Idemobi, Ellis I. 2011. The Implication of Abraham Maslow's Hierarchy of Needs Theory to Business Activities in Nigeria. Afr. J. Soc, 1 (1): 168-178.

Jakob Sumardjo. 1991. Pengantar Novel Indonesia. Bandung: Citra Aditya Bhakti.

Kurniasih, Imas \& Sani, Berlin. 2014. Implementasi Kurikulum 2013 Konsep \& Penerapan. Surabaya: Kata Pena.

Lestari, Puji Budiningrum. 2014. Kepribadian Tokoh dan Nilai Pendidikan Novel Pulang Karya Leila S. Chudori. Tesis. S2 Pascasarjana UNS. Surakarta. ((Unbli shed)

LexyJ.Moleong.2000.Metode Penelitian Kualitatif. Bandung : P.T. Remaja Rosdakarya.

Maslow, Abraham. 1994. Motivasi dan Kepribadian 1. (Terjemahan Nurul Imam). Bandung: Pustaka Binaman Pressindo.

Melani Budianta,dkk. 2006. Membaca Sastra: Pengantar Memahami Sastra Untuk Per guruan Tinggi. Magelang: Indonesia Tera.

Nugraheni Eko Wardhani. 2009. Makna Totalitas dalam Karya Sastra. Solo: UNS

Nyoman Kutha Ratna. 2001. Teori, Metode, dan Teknik Penelitian Sastra. Yogyakarta: Pustaka Pelajar.

Pelajar.

2004. Teori, Metode, dan Teknik Penelitian Sastra. Yogyakarta: Pustaka 2011. Paradigma Sosiologi Sastra. Yogyakarta: Pustaka Pelajar

Pulido, Dennis H. 2011. Saving the Savior: A Deconstruction of the Novel Viajero by F. Sioni Jose. Eng. J. Lang, 17(1):79-92.

Sangidu. 2004. Penelitian Sastra : Pendekatan, Teori, Metode, Teknik, dan Kiat. Yogyakarta: UGM Press. 
LINGUA, Vol. 14, No. 2, September 2017

p ISSN: 1979 9411; e ISSN: 2442 238X

Http://lingua.pusatbahasa.or.id; Email: presslingua@gmail.com

Center of Language and Culture Studies, Surakarta, Indonesia

Lanua, Maretin Ardile, Rhian; Saddhono, Kundharu \& Supana. 2017. Struktur Instrinsik

Novel Kepanggang Wirang Tiwiek SA and Implikasinya dalam Pembelajaran Bahasa Jawa di SMA. Lingua, (2017), 14(2): 155 180.

Sapardi Djoko Damono. 1987. Sosiologi Sastra (Sebuah Pengantar Ringkas). Jakarta: Pusat Pembinaan dan Pengembangan Bahasa Departemen Pendidikan dan Kebuda yaan.

Sarwono, Sarlito W. 2010. Pengantar Psikologi Umum. Jakarta: Rajawali Press

Sayuti, Suminto A. 2000. Perkenalan dengan Prosa Fiksi. Yogyakarta: Gema Media.

Soedarsono, R.M. 1985. Keadaan dan Perkembangan Bahasa, Sastra, Etika, Tatakram a, dan Seni Pertunjukan Jawa, Bali, dan Sunda. Yogyakarta: Proyek Penelitian dan Pengkajian Kebudayaan Nusantara.

Soedono Hadi. 2003. Pendidikan Suatu Pengantar. Surakarta: UNS Press.

Stanton, Robert. 2007. Teori Fiksi. Yogyakarta: Pustaka Pelajar

Suwardi Endraswara. 2011. Metodologi Penelitian Sastra: Epistemologi, Model, Teori, dan Aplikasi. Yogyakarta: FBS Universitas Negri Yogyakarta. 2003. Metodologi Penelitian Sastra. Yogyakarta: Pustaka Widyatama

Teeuw. 1988. Sastra dan Ilmu Sastra : Pengantar Teori Sastra. Jakarta: Pustaka Jaya.

Wellek, Rene. 1989. Teori Kesusastraan. Jakarta: PT. Gramedia.

Wahda, Mahmoud and Lawrence G. Bridwell. 1976. Masllow Reconsidered: A Review of Research on the Need Hierarchy Theory. USA. J. Hum, 1(5): 212-240.

Winda Dwi Lestari. 2015. Analisis Penokohan dan Nilai Pendidikan Budi Pekerti dalam Novel Ngulandara Karya Margana Djajaatmadja Serta Relevansinya sebagai Materi Ajar Apresiasi Sastra Jawa di SMA. Skripsi. FKIP UNS. Surakarta. (Unblished)

Yudiono, K.S. 2000. Ilmu Sastra (Ruwet, Rumit, dan Resah). Semarang: Mimbar. 